\title{
A brief discussion on the history of the emergence of corporate governance in Brazil
}

DOI: $10.46932 /$ sfjdv1n4-005

Received in: August 1st, 2020

Accepted in: September 30th, 2020

Anderson Catapan

Post-doctorate in Management from Universidade Fernando Pessoa (Portugal), PhD in Administration from PUCPR, Master in Accounting and Finance from UFPR, Electrical Engineer from UFPR and Bachelor of Accounting from PUCPR.

Professor of the Master and Doctorate in Planning and Public Governance at the Federal Technological University of Paraná.

Adress: 2925 Mendes Leitão Av., ap. 504, Centro, Sao Jose dos Pinhais/PR, Brazil.

E-mail: catapan@utfpr.edu.br

\begin{abstract}
This short essay aims to illustrate and discuss the history of the creation and emergence of corporate governance in Brazil. For this, the initial theoretical frameworks of governance are addressed, going through the Brazilian laws that address governance.
\end{abstract}

Keywords: Governance, legislation, history.

\section{EMERGENCE OF GOVERNANCE IN BRAZIL}

Andrade and Rosseti (2009) argue that the expansionist process started in the 1930s and the power of corporations are initial factors that led to the emergence of governance. They also state that during this period there were significant technological advances, an increase in production scales reaching serial production, evolution of the capital market, transnationalization of companies and major mergers and acquisitions. Berle and Means (1932) explain that this process led to the dilution of the companies' control capital, causing a divorce between shareholders and company managers. Andrade and Rosseti (2009) list some determining factors for the dispersion of the control capital of companies: (1) The constitution of large companies in the form of corporations and the financing of their growth by public subscription of new issues of shares; (2) the IPO of closed companies and the increase in the number of companies listed on stock exchanges; (3) an increase in the number of investors in the capital market, the increasing diversification of their portfolios and the consequent fractionation of company ownership; (4) the succession processes, triggered by the death of the founders of the companies; (5) the merger processes of the large companies that, at the same time, increase the number of shareholders, but in most cases reduce the share of each one in the total expanded capital. 
This dispersion led to changes in companies, illustrated by Andrade and Rosseti (2009), starting with the separation of ownership and management: with the death of the founders of the companies and the consequent succession process, the advance of publicly-held corporations and the development of the market of capital changed the power structure in companies. Thus, the founding-owners, who were previously the managers of the companies, were replaced by contracted executives.

Berle and Means (1932), regarding the objectives of the companies, explain that they stopped being limited to the maximization of profits, since the administrators saw, among others, an increase in their own gains, instead of maximizing results for the shareholders. These conflicts of ownership and management were the main milestone for the emergence of corporate governance, according to Berle and Means (1932), because the conflicts arising from interests that are not perfectly symmetrical led to the rapprochement of ownership and management, through the path of diffusion and adoption of good corporate governance practices.

The decades from 30 to 80 were marked by the growth of corporations and the beginning of hiring CEOs (Chief Executive Officers), or presidents of companies. Initially, they did not have large remunerations, which began to increase significantly over time via a bonus on profits, a fact that started the conflict of interest between managers and shareholders.

In the 1990s, the Cadbury Report was published, considered the first code of good corporate governance practices. The document, prepared by a commission coordinated by Adrian Cadbury, emerged in response to scandals registered in the corporate and financial market in England in the late 1980s (IBGC, 2010).

In Brazil, in 1995 the Brazilian Institute of Board Members (IBCA), the current Brazilian Institute of Corporate Governance (IBGC), was founded. In 1997, Law 9,457 was passed reformulating the Corporations Law (Law 6,404 / 1976). Law 9,457 / 97 revokes the Tag Along of 100\% for ordinary shareholders, being considered a setback in the issue of minority shareholders' rights. In 2000, the São Paulo Stock Exchange (Bovespa) officially launched the differentiated corporate governance segments, segmenting them into Level 1, Level 2 and New Market.

In November 2001, some of the problems of accounting fraud emerged, especially at Enron. Subsequently, several North American companies are required to redo their financial statements. As a consequence, the American auditing firm Arthur Andersen ceases operations after being accused of obstructing the work of justice. In 2001, Bovespa created the Corporate Governance Index (IGC) whose objective is to measure the performance of a portfolio made up of shares of companies that present good levels of governance. Furthermore, the Brazilian Corporate Law was reformulated, with Law 10,303 / 2001, showing timid progress in relation to the initial project. 
In mid-2002, the US Congress passed the Sarbanes-Oxley (SOX) Act in July, in response to corporate scandals involving major companies in the country, such as Enron, Worldcom and Tyco, among others. In the following month, the Securities and Exchange Commission (SEC) publishes some complementary rules and the New York Stock Exchange approves new corporate governance requirements as a condition for listing companies.

In 2005, as illustrated by Andrade and Rosseti (2009), during the Annual London Conference, the International Corporate Governance Network (ICGN) endorses the principles of corporate governance, which were discussed for a year by its members and states that it believes that companies around the world must receive clear and objective guidance on how to implement the principles of corporate governance.

\section{FINAL DISCUSSION}

From then on, an era of implantation of corporate governance practices in companies around the world began. According to rating agencies, which measure levels of governance practices, these have been effectively adopted by an increasing number of companies, levels which have been increasing year by year.

\section{REFERENCES}

Andrade, A. \& Rossetti, J. P. 2009. Governança Corporativa: fundamentos, desenvolvimento e tendências. 4 ed. São Paulo: Atlas.

IBGC - Instituto Brasileiro de Governança Corporativa. 2004. Código das Melhores Práticas de Governança Corporativa. Disponible in: http://www.ibgc.org.br. 